\begin{tabular}{|l|l|l|l|l|l|}
\hline J. Tek. Ling. & Vol. 10 & No. 1 & Hal. 114 - 119 & Jakarta, Januari 2009 & ISSN 1441-318X \\
\hline
\end{tabular}

\title{
KARAKTERISTIK DAN PERTUMBUHAN KONSORSIUM MIKROBA LOKAL DALAM MEDIA MENGANDUNG MINYAK BUMI
}

\author{
Wage Komarawidjaja \\ Peneliti di Pusat Teknologi Lingkungan \\ Badan Pengkajian dan Penerapan Teknologi
}

\begin{abstract}
Laboratory microcosm observation were conducted to study the effect of media culture containing oil spill in microbial growth ability. Laboratory microcosms was inoculated with oil microbial consortia isolated from oil spill sample in Cepu oil field. Based on the colony characteristic differentiation, 5 microbial types identified from the sample. At the end of enrichment period and acclimatization on the $\mathrm{BH}$ media containing 5\% Cepu crude oil, all isolates as microbial consortia put into growth experiment media.

The experiment proved that microbes could be able utilizing oil as carbon source for their cell multiplication. The results showed the more the turbidity concentration increase, the more the microbial population rise. These studies indicates that reducing oil spill utilizing in situ bioremediation technologies can be realized.
\end{abstract}

Keywords : spill oil, oil pollution, bioremediation

\section{PENDAHULUAN}

\subsection{Latar Belakang}

Minyak bumi merupakan salah satu sumber energi utama yang tidak pernah lepas dari kehidupan manusia. Terlepas dari semua hal positif yang didapat dari penggunaan minyak bumi sebagai sumber energi, ada beberapa hal negatif yang sebaiknya dijadikan pertimbangan ketika menggunakan minyak bumi dalam eksploitasi, pengolahan, maupun dalam pendistribusian. Oleh karena itu, Pemanfaatan minyak bumi yang tidak memperhatikan kelestarian lingkungan tentu akan merugikan manusia itu sendiri dan pada akhirnya pencemaran lingkungan tersebut akan berdampak negatif khususnya kepada kesehatan masyarakat.
Fenomena tersebut memacu upaya penanggulangan melalui berbagai proses kimia, fisik dan biologi untuk menekan akumulasi senyawa organic toksik pada lingkungan tanpa menimbulkan kerusakan ekosistem di kemudian hari.

Upaya pemulihan lingkungan tercemar limbah beracun berbahaya (B3) tersebut membutuhkan suatu prosedur yang sistimatik, dilakukan dengan cara bertahap dan dilaksanakan dengan pendekatan multidisiplin yang diintegrasikan dari berbagai disiplin keilmuan yang berbeda.

Sebenarnya, sudah banyak tersedia teknologi untuk digunakan dalam rangka upaya pemulihan lahan tercemar 
(remediasi), namun yang terpenting adalah bagaimana memilih teknologi yang sesuai dengan jenis bahan pencemar, sesuai dengan karakeristik lahan tercemar, biaya yang dibutuhkan serta factor waktu sebagai pembatas.

Salah satu teknik remediasi yang memanfaatkan mikroba dikenal sebagai Bioremediasi. Hal ini sangat menarik, karena prosesnya ramah lingkungan dengan biaya lebih kompetitif dibandingkan dengan teknik fisikokimia. ${ }^{1)}$

Pengertian dari bioremediasi sendiri adalah proses penguraian limbah (pencemar) menggunakan agen biologi (mikroba) yang dilakukan dalam kondisi terkendali (controlled condition). Proses bioremediasi dapat terjadi secara alamiah oleh mikroba yang terdapat pada lingkungan tercemar (intrinsict bioremediation). Meskipun demikian, sering kali dilakukan beberapa hal untuk mempercepat proses tersebut. Contohnya dengan menambahkan mikroba (exogenous microbe), nutrien, donor dan atau akseptor electron. ${ }^{2)}$
Bakteri yang diketahui memiliki kemampuan dalam mendegradasi minyak antara lain Pseudomonas aeruginosa, Serratia marcescens, Acinetobacter baumannii, Baccillus megaterium, Baccillus cereus, Fussarium vertiaculloide, dan Candida tropicalis. ${ }^{3,4,5)}$

Bakteri yang terdapat di alam tidak hanya berada dalam bentuk tunggal tetapi campuran. Begitupula, bakteri yang terdapat pada daerah tercemar minyak mentah. Mikrobai petrofilik yang terdapat pada daerah tercemar minyak mentah tidak hanya berada dalam bentuk tunggal tetapi campuran. Satu jenis mikroba yang bekerja sendiri tidak akan mampu untuk mendegradasi beragam senyawa yang terdapat pada minyak mentah ${ }^{6}$. Penggunaan konsorsium mikroba cenderung memberikan hasil yang lebih baik dibandingkan penggunaan isolat tunggal, karena diharapkan kerja enzim dari tiap jenis mikroba dapat saling melengkapi untuk dapat bertahan hidup menggunakan sumber nutrien yang tersedia dalam minyak bumi mentah tersebut. ${ }^{7)}$
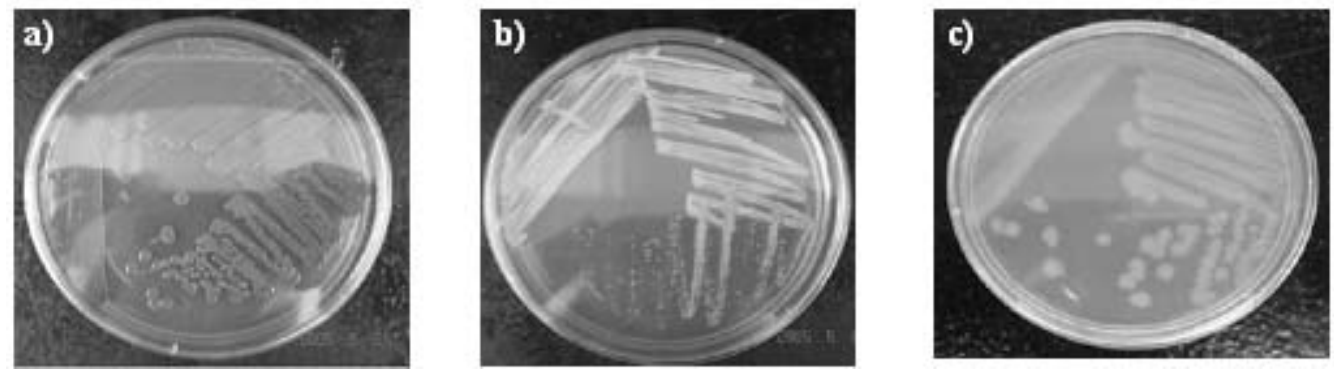

Gambar 1.Profil bakteri pendegradasi hidrokarbon.

a) Serratia marcescens;

b) Acinetobacter baumannii;

c) Pseudomonas sp. (Malatova 2005).

Teknik ini dilakukan berdasarkan optimasi proses biologi dalam mengurangi bahkan memulihkan dari bahan pencemar. Inti dari bioremediasi lahan tercemar bahan organik adalah upaya menghilangkan efek racun (detoks) atau dengan menghidrolisis bahan penemar menjadi karbon dioksida $\left(\mathrm{CO}_{2}\right)$ dan air $\left(\mathrm{H}_{2} \mathrm{O}\right)$.

\subsection{Tujuan}

Oleh karena itu, penting diketahui informasi tentang karakteristik dan pertumbuhan konsorsium mikroba lokal (indigenous) yang memiliki potensi mendegradasi beragam senyawa yang terdapat pada minyak mentah. 


\section{METODOLOGI}

\subsection{Alat dan Bahan}

Peralatan yang digunakan selama penelitian ini adalah inkubator, shaker, ruang laminar, peralatan gelas seperti cawan petri, erlenmeyer, vorteks, gelas piala, $\mathrm{pH}$ meter, JASCO V-530 UV/Vis Spektrofotomer, high blower aerator, neraca analitik, penangas air, kertas saring, oven, autoklaf dan pengaduk magnetik (magnetic stirrer).

Bahan-bahan yang digunakan antara lain minyak mentah (crude oil) dari lapangan blok Cepu, akuades, media Bushnell-Haas $(\mathrm{BH})$ dengan komposisi $\mathrm{MgSO}_{4} 0.2 \mathrm{~g} / \mathrm{L}$, $\mathrm{KH}_{2} \mathrm{PO}_{4} 1 \mathrm{~g} / \mathrm{L}, \mathrm{K}_{2} \mathrm{HPO}_{4} 1 \mathrm{~g} / \mathrm{L}, \mathrm{FeCl}_{3} \cdot 3 \mathrm{H}_{2} \mathrm{O}$ $0.05 \mathrm{~g} / \mathrm{L}, \mathrm{CaCl}_{2} \cdot 2 \mathrm{H}_{2} \mathrm{O} 0.02 \mathrm{~g} / \mathrm{L}$, yeast extract $12 \mathrm{~g} / \mathrm{L}, \mathrm{NH}_{4} \mathrm{NO}_{3} 1 \mathrm{~g} / \mathrm{L}$. Selain itu juga digunakan media nutrien agar (NA) yang terdiri atas pepton $15 \mathrm{~g} / \mathrm{L}$, yeast extract $3 \mathrm{~g} /$ L, NaCl 6 g/L, Glukosa 1 g/L, dan agar 12 g/L.

\subsection{Metoda Penelitian}

\section{a. Stok Isolat}

Isolat yang digunakan selama penelitian merupakan hasil isolasi dari sampel minyak mentah (crude oil) dari sumur minyak yang terdapat di blok cepu. Sampel setelah dikembangbiakan dan diaklimatisasikan dalam media tumbuh mengandung $5 \%$ minyak mentah serta secara visual menunjukkan kemampuan dalam mendegradasi minyak mentah, baru kemudian diuji kemampuannya dalam memanfaatkan minyak mentah sebagai sumber nutrien untuk pertumbuhannya.

\section{b. Parameter yang Dianalisa}

Pengambilan sampel dilakukan setiap 3-5 hari sekali hingga pengambilan kelima dan seterusnya dilakukan pengambilan sampel tiap satu minggu sekali. Parameter yang dianalisis antara lain adalah $\mathrm{pH}$, jumlah koloni (CFU/ml) dan pertumbuhan bakteri. Sampel yang dianalisa berasal dari media perlakuan 1 dengan pemberian konsorsium mikroba 1 kali, media perlakuan 2 dengan pemberian konsorsium mikroba 2 kali, dan media kontrol.

- Jumlah Koloni dan Kurva Standar. Jumlah koloni dihitung dengan menggunakan teknik standard plate count. Sebanyak 100 il bakteri pada faktor pengenceran $10^{-5}, 10^{-6}$, dan $10^{-7}$ disebar pada media NA kemudian diinkubasi pada suhu $30^{\circ} \mathrm{C}$ selama 48 jam. Jumlah koloni yang tumbuh kemudian dicatat dan diplotkan dengan nilai absorban pada panjang gelombang $600 \mathrm{~nm}$. Kurva standar didapat dari hubungan antara nilai absorban dan jumlah koloni.

- Pertumbuhan Bakteri (Ciawi et al.). Pertumbuhan bakteri diukur dengan nilai absorban pada panjang gelombang 600 $\mathrm{nm}$. Sampel diencerkan terlebih dahulu dengan $\mathrm{NaCl}$ fisiologis $(0.9 \%)$ sehingga dihasilkan nilai absorban sampel ${ }^{8)}$
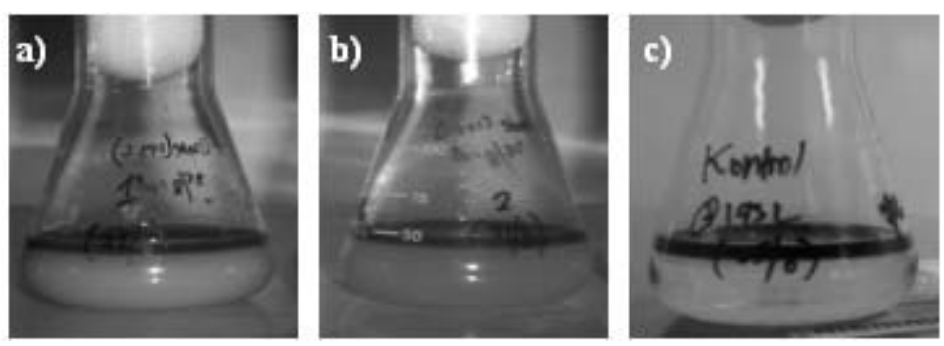

Gambar 2. Isolat cepu yang digunakan dalam proses screening, a) isolat 1 ; b) 2; c) kontrol. 


\section{HASIL DAN PEMBAHASAN}

\subsection{Karakteristik Mikroba}

Berdasarkan bentuk koloni yang tampak pada plate agar, diperolah gambaran beberapa jenis mikroba dengan karakteristik sebagai berikut :

- Koloni berwarna putih, mengkilat, permukaan halus, cembung, sisi rata.

- Koloni berwarna kuning, mengkilat, permukaan halus, cembung, sisi rata.

- Koloni berwarna putih, mengkilat, permukaan halus, agak cekung di tengah, sisi rata.

- Koloni berwarna putih, tidak mengkilat, rata dengan medium, sisi rata, pada permukaannya terdapat gurat-gurat.

- Koloni putih, mengkilat, sisi tidak rata / bergerigi.

\subsection{Profil Pertumbuhan Mikroba}

Untuk memudahkan dalam perhitungan pertumbuhan mikroba, dibuat kurva standar yang dihasilkan dari plot nilai absorban terhadap jumlah koloni yang tumbuh pada cawan agar. Jumlah koloni yang tumbuh dari sampling kedua hingga kelima diplotkan terhadap nilai absorbannya pada panjang gelombang $600 \mathrm{~nm}$, sehingga diperoleh kurva standar dengan persamaan $Y=$ $0,0002 X+0,3455$, dimana nilai $R^{2}=0,713$ sebagai pendekatan dalam memperoleh jumlah kepadatan pertumbuhan mikroba.

Profil pertumbuhan bakteri tersebut sampai pengambilan sampel terakhir dihitung berdasarkan pendekatan nilai absorban pada panjang gelombang $600 \mathrm{~nm}$. Meskipun diketahui bahwa nilai absorban dihasilkan dari serapan biomassa yang hidup dan mati, dari kurva standar yang diperoleh dapat diperkirakan jumlah biomassa yang hidup dalam media. Pola Pertumbuhan bakteri sampai dengan pengambilan sampel VIII atau setelah sekitar

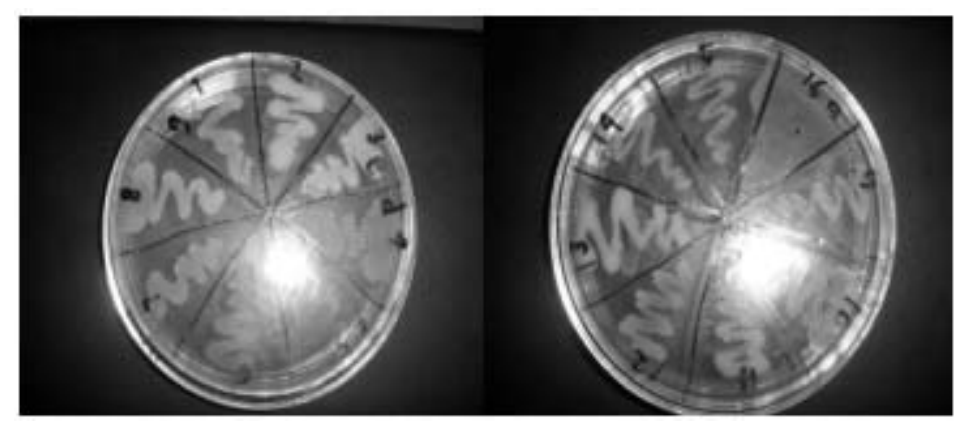

Gambar 3. Kultur hasil isolasi

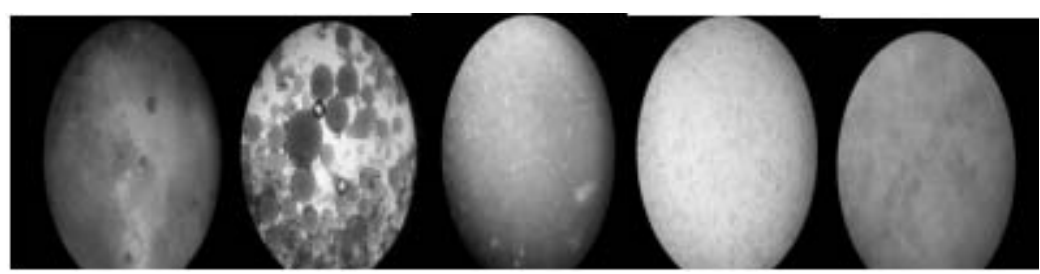

Gambar 4. Performan kelima kultur mikroba di bawah mikroskop 
45 hari disajikan pada Gambar 5 . Hingga pengambilan sampel kelima, teramati bentuk grafik parabola untuk semua perlakuan yaitu, mencapai nilai tertinggi pada pengambilan sampel III untuk dua perlakuan yang sama ( $1 x$ dan $2 x$ ) dan pada pengambilan sampel II untuk blanko (0). Adapun titik terendah dari grafik teramati pada pengambilan sampel V. Setelah pengambilan sampel $\mathrm{V}$, teramati bahwa terjadi peningkatan nilai absorban dari tiap perlakuan. Penambahan mikroba dengan jumlah yang sama pada perlakuan $2 x$ dilakukan setelah pengambilan sampel IV. minyak-media yang dapat dimanfaatkan oleh bakteri sebagai sumber karbon. Data tersebut didukung oleh hasil penelitian yang menyatakan bahwa nilai indeks emulsi $\left(\mathrm{IE}_{24}\right)$ tercapai maksimal setelah inkubasi selama 5-10 hari. $^{9 \text { ) }}$

Selanjutnya titik tertinggi kedua tercapai pada pengambilan sampel VIII untuk perlakuan $1 x$ dan $2 x$. Dengan semakin bertambahnya nilai absorban diharapkan sebagai indikasi pertambahan kepadatan mikroba semakin meningkat atau dengan kata lain konsorsium mikroba

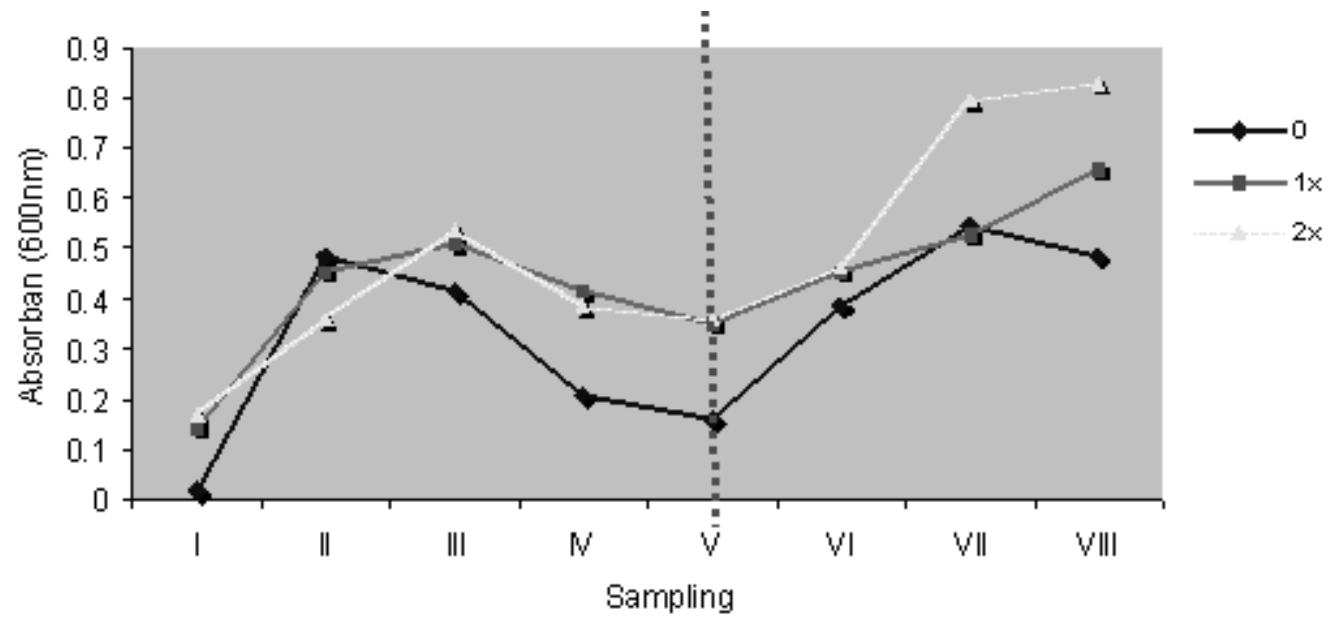

Gambar 5 Profil pertumbuhan bakteri pada tiap perlakuan

Pertumbuhan bakteri biasanya dipengaruhi oleh banyak faktor, diantaranya adalah nilai $\mathrm{pH}$, suhu, nutrien, ketersediaan oksigen, dan faktor-faktor lainnya ${ }^{7)}$. Dari grafik profil pertumbuhan bakteri (Gambar 5), teramati bahwa pertumbuhan bakteri diantara perlakuan $1 \mathrm{x}$ dan $2 \mathrm{x}$ berbeda dengan blanko. Titik tertinggi pertama pertumbuhan mikroba terjadi pada pengambilan sampel III atau setelah masa inkubasi 9 hari. Perbedaan pertumbuhan tersebut diduga terjadi karena adanya perbedaan produksi biosurfaktan yang dihasilkan oleh konsorsium bakteri pada masing-msing perlakuan. Biosurfaktan berperan dalam pembentukan emulsi telah mampu memanfaatkan minyak mentah sebagai sumber karbon dalam melipat gandakan kepadatan sel dalam media uji tersebut. Rahman et al. dalam penelitiannya yang menggunakan konsorsium dari lima bakteri menyatakan bahwa populasi bakteri tertinggi tercapai setelah 60 hari inkubasi. Hasil tersebut didapat dari nilai absorban pada panjang gelombang $595 \mathrm{~nm}$. Waktu inkubasi selama penelitian sekitar 45 hari, sehingga dapat dipastikan bahwa jumlah bakteri yang tumbuh dalam media masih melakukan aktivitasnya dalam mendegradasi hidrokarbon. Pertumbuhan bakteri yang optimal merupakan salah satu indikasi 
bahwa bakteri dapat bertahan hidup dalam media garam minimal (media $\mathrm{BH}$ ) yang disuplementasi oleh minyak mentah.

Pertumbuhan mikroba yang baik tersebut didukung oleh perubahan nilai $\mathrm{pH}$ selama penelitian berada pada kisaran 7.08.5 mengingat kondisi $\mathrm{pH}$ merupakan salah satu faktor yang berpengaruh terhadap pertumbuhan bakteri. Nilai $\mathrm{pH}$ yang optimal berkaitan erat dengan kerja enzim bakteri, karena degradasi minyak dilakukan oleh serangkaian enzim yang terdapat pada bakteri. Pada nilai pH sekitar 5.5-8.0 bakteri yang mendegradasi hidrokarbon masih melakukan aktivitasnya ${ }^{3,10,11)}$. Meskipun demikian nilai $\mathrm{pH}$ optimum berada pada kisaran $\mathrm{pH}$ netral dan sedikit basa (slight base $)^{3,7)} \quad$ Apabila dihubungkan dengan grafik profil pertumbuhan bakteri (Gambar 5), nilai absorban tertinggi tercapai pada nilai pH 7.6 yaitu pada pengambilan sampel VIII.

\section{PENUTUP}

Dari pengamatan sampel mikroba dari lapangan minyak Cepu dapat ditarik suatu kesimpulans ebagai berikut:

1. Dari hasil pengayaan isolat lapang, telah diperoleh konsorsium untuk dikembangkan menjadi kelompok mikroba pendegradasi minyak.

2. Pada pengamatan pertumbuhan kosorsium mikroba menunjukkan peningkatan yang cukup baik, meskipun belum diikuti dengan pengukuran pemanfaatan minyak yang digunakan oleh mikroba sebagai sumber karbon.

\section{DAFTAR PUSTAKA}

1. Cookson, John T, Jr, 1995. Bioremediation Engineering : Design and Application. United States of America : McGraw-Hill, Inc.

2. Sarwoko M. 2005. Seleksi Teknologi Pemulihan Untuk Ekosistem Laut Tercemar Minyak. Seminar Nasional
Teori dan Aplikasi Teknologi Kelautan ITS, Surabaya, 24 November 2005.

3. Wongsa $\mathrm{P}$ et al. 2004. Isolation and characterization of novel strains of Pseudomonas aeruginosa and Serratia marcescens possessing high effeciency to degrade gasoline, kerosene, diesel oil, and lubricating oil. Cur Microbiol 49:415-422.

4. Malatova K. 2005. Isolation and characterization of hydrocarbon degrading bacteria from environmental habitats in western New York state. Thesis: Department of Chemistry, Rochester Institute of Technology.

5. Ugochukwu KC, Agha NC, Ogbulie. 2008. Lipase activities of microbial isolates from soil contaminated with crude oil after bioremediation. African J Of Biotechnol. 7:2881-2884.

6. Carsten L. 2002. The Promise of Bioremediation. Northwest Science and Technology: 37-39.

7. Okoh Al. 2006. Biodegradation alternative in the cleanup of petroleum hydrocarbon pollutants. Biotechnol. And Molecular Biology Review 1 (2):3850.

8. Ciawi $Y$ et al. The degradation of diesel oil by consortium of bacteria in shakeflask cultures.

9. Kumar M et al. 2006. Enhancement of oil degradation by co-culture of hydrocarbon degrading and biosurfactant producing bacteria. Polish J of Microbiol 55:139-146

10. Kato $\mathrm{S}$ et al. Application of microbial consortium system to wastewater from biodiesel fuel generator.

11. Arafa MA. 2003. Biodegradation of some aromatic hydrocarbon (BTEXs) by a bacterial consortium isolated from polluted site in Saudi Arabia. Pakistan J Of Biol Sci. 6(17): 1482-1486. 